\title{
A 2015 Social Accounting Matrix (SAM) for Mozambique
}

António S. Cruz ${ }^{1}$, Fausto Mafambissa², Mónica Magáua ${ }^{3}$, Vincenzo Salvucci ${ }^{4}$, and Dirk van Seventer ${ }^{5}$

February 2018 
Abstract: This paper documents a 2015 Social Accounting Matrix (SAM) for Mozambique. The SAM is built using unpublished Instituto Nacional de Estatística (INE) industry-level production accounts, commodity-level supply-demand balances and a supply matrix, together with national accounts, National Directorate of Planning and Budget (DNPO) government statistics and IMF balance of payment statistics (all for the year 2015), INE household and labour market survey data for 2014-15 and a use matrix from a 2007 SAM for Mozambique. It provides a detailed representation of the Mozambican economy and identifies 55 activities and commodities. Labour is disaggregated by education attainment level and household income and expenditure by per capita expenditure quintiles both for urban and rural areas. The SAM features production for home consumption as reported in the unpublished INE accounts and the INE household survey data and also presents government, investment, and foreign accounts. The SAM is a useful database for conducting economy-wide impact asdsessments, including multiplier analysis and computable general equilibrium (CGE) modelling.

Keywords: Social accounting matrix, national accounts, supply table, use table, cross-entropy SAM estimation

JEL classification: C63, E01, E16, P44

Acknowledgements: We are grateful to Rob Davies, Channing Arndt, and James Thurlow for their comments and inputs to this paper.

Link to the 2015 National Social Accounting Matrix.

This is an updated version from that published in February 2018, which required small data revision in Section 3.

\footnotetext{
${ }^{1}$ Independent contractor, Sarajevo, Bosnia-Herzegovina; ${ }^{2}$ Economic and Financial Studies Directorate, Ministry of Economy and Finance, Maputo, Mozambique; ${ }^{3}$ Directorate of National Accounts and Global Indicators, National Institute of Statistics, Maputo, Mozambique; ${ }^{4}$ Research Fellow, UNU-WIDER, Helsinki, Finland; ${ }^{5}$ Consultant, UNU-WIDER, Helsinki, Finland, corresponding author, email: denves@xtra.co.nz .

This study has been prepared within the project on 'Inclusive growth in Mozambique-scaling-up research and capacity' implemented in collaboration between UNU-WIDER, University of Copenhagen, University Eduardo Mondlane, and the Mozambican Ministry of Economics and Finance. The project is financed through specific programme contributions by the governments of Denmark, Finland, Norway, and Switzerland.
}

Copyright (C) UNU-WIDER 2018

Information and requests: publications@wider.unu.edu

ISSN 1798-7237 ISBN 978-92-9256-462-9 https://doi.org/10.35188/UNU-WIDER/2018/462-9

Typescript prepared by Ans Vehmaanperä.

The United Nations University World Institute for Development Economics Research provides economic analysis and policy advice with the aim of promoting sustainable and equitable development. The Institute began operations in 1985 in Helsinki, Finland, as the first research and training centre of the United Nations University. Today it is a unique blend of think tank, research institute, and UN agency — providing a range of services from policy advice to governments as well as freely available original research.

The Institute is funded through income from an endowment fund with additional contributions to its work programme from Finland, Sweden, and the United Kingdom as well as earmarked contributions for specific projects from a variety of donors.

Katajanokanlaituri 6 B, 00160 Helsinki, Finland

The views expressed in this paper are those of the author(s), and do not necessarily reflect the views of the Institute or the United Nations University, nor the programme/project donors. 
List of acronyms

CGE Computable general equilibrium

DNPO Direcção Nacional de Planificação e Orçamento (National Directorate of Planning and Budget)

GDP Gross domestic product

INE Instituto Nacional de Estatística (National Institute of Statistics)

MEF Ministério de Economia e Finanças (Ministry of Economy and Finance)

SAM Social Accounting Matrix

SUT Supply-use table 
This paper outlines the construction of a 2015 social accounting matrix (SAM) for Mozambique. A SAM is a consistent data framework that captures the information contained in the national income and product accounts and a supply-use table (SUT), as well as the monetary flows between institutions. Since it is an ex-post accounting and square framework, total receipts (row totals) must equal total payments (column totals) for each account reported by the SAM. The required data is drawn from various sources and must therefore be compiled and made consistent. This process is valuable since it helps identify inconsistencies among statistical sources. For example, there are invariably differences between the incomes and expenditures reported in household surveys and national accounts. SAMs are economy-wide databases that are used in conjunction with analytical techniques to strengthen the evidence underlying policy decisions.

Section 2 reviews the general structure of SAMs and Section 3 presents the key features of a 2015 SAM for Mozambique. A number of steps are involved. The first step in constructing the Mozambican SAM is compiling national accounts and other official data sources into a consistent SAM framework. The second step then draws on survey information to disaggregate labour and household accounts. Section 3 describes the data sources used to construct the SAM and the finalization of detailed SAM accounts is discussed in Section 4. Section 5 reports on some key data issues that were noted during the compilation process which highlights the need for further work on this SAM, while Section 6 summarizes.

The 2015 SAM is based on unpublished INE industry-level production accounts, commoditylevel supply-demand balances and a supply matrix for 2015 together with National Directorate of Planning and Budget (DNPO) government statistics and IMF balance of payment statistics (all for the year 2015), unpublished INE household and labour market survey data for 2014-15 (INE, 2015) and a use matrix from a 2007 SAM for Mozambique (Arndt and Thurlow 2014). It provides a detailed representation of the Mozambican economy and separates 55 activities and commodities. Labour is disaggregated by education attainment level and household income and expenditures by per capita expenditure quintiles both for urban and rural areas. The SAM features production for home consumption as reported in the unpublished INE accounts and INE (2015) household survey data and also identifies government, investment, and foreign accounts. The construction of the SAM is part of the joint "Scaling Up Research and Capacity Building on Improved Development Policy in Mozambique for the period 2016-19" initiative, a collaboration of the Mozambique Ministry of Economy and Finance, University Eduardo Mondlane, UNU-WIDER and Copenhagen University. 
Table 1: Basic structure of a 2015 SAM for Mozambique

\begin{tabular}{|c|c|c|c|c|c|c|c|c|c|c|c|c|c|c|c|c|}
\hline & Activities & Commodities & Land & Labour & Capital & Enterprises & Households & Government & Net activity taxes & $\begin{array}{c}\begin{array}{c}\text { Net product } \\
\text { taxes }\end{array} \\
\end{array}$ & Import duties & Income taxes & $\begin{array}{l}\text { Changes in } \\
\text { inventories } \\
\end{array}$ & Accumulation & Rest of the world & \\
\hline Activities & & $\begin{array}{c}\text { Marketed output } \\
\text { of total domestic } \\
\text { economy }\end{array}$ & & & & & $\begin{array}{c}\text { Output for } \\
\text { domestic } \\
\text { consumption }\end{array}$ & & & & & & & & & Gross output \\
\hline Commodities & $\begin{array}{c}\text { Intermediate } \\
\text { Inputs }\end{array}$ & $\begin{array}{c}\text { Transaction } \\
\text { margins }\end{array}$ & & & & & $\begin{array}{c}\text { Final marketed } \\
\text { consumption } \\
\text { expenditure by } \\
\text { households }\end{array}$ & \begin{tabular}{|c|} 
Final \\
consumption \\
expenditure by \\
general \\
government \\
\end{tabular} & & & & & $\begin{array}{l}\text { Change in } \\
\text { inventories }\end{array}$ & $\begin{array}{c}\text { Gross fixed } \\
\text { capital formation }\end{array}$ & $\begin{array}{c}\text { Exports of goods } \\
\& \text { services }\end{array}$ & Total demand \\
\hline Land & $\begin{array}{c}\text { Compensation } \\
\text { for land use } \\
\end{array}$ & & & & & & & & & & & & & & & $\begin{array}{c}\begin{array}{l}\text { Income from } \\
\text { land }\end{array} \\
\end{array}$ \\
\hline Labour & $\begin{array}{c}\text { Compensation of } \\
\text { employees }\end{array}$ & & & & & & & & & & & & & & $\begin{array}{c}\text { Compensation of } \\
\text { Mozambican } \\
\text { residents in the } \\
\text { rest of the world }\end{array}$ & Labour income \\
\hline Capital & $\begin{array}{c}\text { Net operating } \\
\text { surplus + } \\
\text { Consumption of } \\
\text { fixed capital } \\
\text { (Depreciation) } \\
\end{array}$ & & & & & & & & & & & & & & \begin{tabular}{|c|} 
Investment \\
income (primary \\
income) receipts
\end{tabular} & Capital income \\
\hline Enterprises & & & & & $\begin{array}{c}\text { Gross operating } \\
\text { surplus of } \\
\text { corporations }\end{array}$ & & & $\begin{array}{l}\text { Government } \\
\text { transfers to } \\
\text { enterprises }\end{array}$ & & & & & & & $\begin{array}{c}\text { Current transfers } \\
\text { from the rest of } \\
\text { the world to } \\
\text { enterprises }\end{array}$ & $\begin{array}{l}\text { Enterprise } \\
\text { earnings }\end{array}$ \\
\hline Households & & & $\begin{array}{c}\text { Household } \\
\text { earnings from } \\
\text { land holdings }\end{array}$ & $\begin{array}{c}\text { Compensation of } \\
\text { residents }\end{array}$ & & 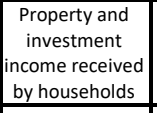 & & $\begin{array}{l}\text { Government } \\
\text { transfers to } \\
\text { households }\end{array}$ & & & & & & & \begin{tabular}{|c|} 
Current transfers \\
from the rest of \\
the world to \\
households \\
\end{tabular} & $\begin{array}{l}\text { Household } \\
\text { earnings }\end{array}$ \\
\hline Government & & & & & $\mid \begin{array}{c}\text { Property income } \\
\text { of the } \\
\text { government }\end{array}$ & \begin{tabular}{|c|} 
Miscellaneous \\
transfers by \\
enterprises to \\
government
\end{tabular} & & 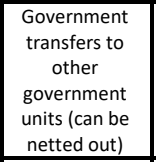 & & $\begin{array}{c}\text { Sales tax } \\
\text { collected and } \\
\text { transferred to } \\
\text { the government }\end{array}$ & $\begin{array}{l}\text { Import duties } \\
\text { collected and } \\
\text { transferred to } \\
\text { the government }\end{array}$ & $\begin{array}{c}\text { Income and } \\
\text { corporate tax } \\
\text { collected and } \\
\text { transferred to } \\
\text { the government }\end{array}$ & & & $\begin{array}{c}\text { Current transfers } \\
\text { from the rest of } \\
\text { the world to } \\
\text { government }\end{array}$ & $\begin{array}{c}\text { Government } \\
\text { receipts }\end{array}$ \\
\hline Net activity taxes & & & & & & & & & & & & & & & & \begin{tabular}{|c|} 
Net other taxes \\
on production in \\
all industries \\
\end{tabular} \\
\hline Net product taxes & & $\begin{array}{l}\text { Taxes on } \\
\text { products }\end{array}$ & & & & & & & & & & & & & & \begin{tabular}{|l|} 
Net taxes on \\
products less \\
import duties
\end{tabular} \\
\hline Import duties & & Import duties & & & & & & & & & & & & & & \begin{tabular}{|l|} 
Import duties \\
\end{tabular} \\
\hline Income taxes & & & & & & Corporate tax & $\begin{array}{c}\text { Income tax on } \\
\text { individuals }\end{array}$ & & & & & & & & & $\begin{array}{c}\text { Current taxes on } \\
\text { income }\end{array}$ \\
\hline $\begin{array}{l}\text { Changes in } \\
\text { inventories }\end{array}$ & & & & & & & & & & & & & & $\begin{array}{l}\text { Change in } \\
\text { inventories }\end{array}$ & & $\begin{array}{l}\text { Change in } \\
\text { inventories }\end{array}$ \\
\hline Accumulation & & & & & & $\begin{array}{c}\text { Corporate } \\
\text { savings }\end{array}$ & $\begin{array}{c}\begin{array}{c}\text { Household } \\
\text { savings }\end{array} \\
\end{array}$ & \begin{tabular}{|c|} 
Government \\
budggt deficit \\
\end{tabular} & & & & & & & \begin{tabular}{|c|}
$\begin{array}{c}\text { Balance on the } \\
\text { current account }\end{array}$ \\
\end{tabular} & Savings \\
\hline Rest of the world & & $\begin{array}{c}\text { Imports of goods } \\
\& \text { services }\end{array}$ & & \begin{tabular}{|c}
$\begin{array}{c}\text { Remittances to } \\
\text { non-resident } \\
\text { workers }\end{array}$ \\
\end{tabular} & \begin{tabular}{|c|} 
Investment \\
income outflows
\end{tabular} & \begin{tabular}{|c|} 
Transfers by \\
enterprises to \\
the rest of the \\
world \\
\end{tabular} & & \begin{tabular}{|c|} 
Government \\
transfers to the \\
rest of the world \\
\end{tabular} & & & & & & & & $\begin{array}{l}\text { Foreign } \\
\text { exchange } \\
\text { outflows }\end{array}$ \\
\hline Total & Gross output & Total Supply & $\begin{array}{c}\text { Distribution of } \\
\text { income from } \\
\text { land }\end{array}$ & $\begin{array}{l}\text { Distribution of } \\
\text { labour income }\end{array}$ & $\begin{array}{l}\text { Distribution of } \\
\text { capital income }\end{array}$ & $\begin{array}{l}\text { Enterprise } \\
\text { outlays }\end{array}$ & $\begin{array}{c}\text { Household } \\
\text { outlays }\end{array}$ & $\begin{array}{l}\text { Government } \\
\text { outlays }\end{array}$ & $\left|\begin{array}{c}\text { Net other taxes } \\
\text { on production in } \\
\text { pll industries }\end{array}\right|$ & $\begin{array}{l}\text { Net taxes on } \\
\text { products less } \\
\text { import duties }\end{array}$ & \begin{tabular}{|c|} 
Taxes on \\
international \\
trade and \\
transactions: \\
Import duties \\
\end{tabular} & $\begin{array}{c}\text { Current taxes on } \\
\text { income }\end{array}$ & $\begin{array}{l}\text { Change in } \\
\text { inventories }\end{array}$ & \begin{tabular}{c|} 
Gross fixed \\
capital formation \\
(investment) + \\
change in \\
inventories \\
\end{tabular} & \begin{tabular}{|c|} 
Foreign \\
exchange inflow
\end{tabular} & \\
\hline
\end{tabular}

Source: Authors' own compilation. 
A SAM is an economy-wide accounting framework that usually represents the real economy of a single country ${ }^{1}$ reported as a square matrix in which each account is represented by a row and a column. Each cell shows the payment from the account of its column to the account of its row the incomes of an account appear along its row, its expenditures down its column. The underlying principle of double-entry accounting requires that, for each account in the SAM total revenue (row total) equals total expenditure (column total). Table 1 shows an aggregate SAM (with verbal explanations in place of numbers) with specific reference to data for Mozambique.

The SAM distinguishes between 'activities' (the entities that carry out production) and 'commodities' (representing markets for goods and non-factor services). SAM flows are valued at producers' prices in the activity accounts and at market prices (including indirect commodity taxes and transactions costs) in the commodity accounts. The commodities consist of output produced by local activities (which are either exported or sold domestically), and imports.

Payments by activities (shown as columns in the SAM) are made to commodity accounts (comprising of locally produced and imported goods and non-factor services (at market prices) i.e., intermediate demand), and factors of production (value-added comprising of operating surplus and compensation of employees, land and/or livestock). The commodity accounts make payments (shown again as columns) to domestic activities, the rest of the world, and various tax accounts (for domestic and import taxes). This treatment allows for the data to model imports as perfect or imperfect substitutes vis-à-vis domestic production.

The government is disaggregated into a core government account and different tax collection accounts, one for each tax type identified in the data. In the SAM, direct payments between the enterprises, households, government and the rest of the world are reserved for transfers as reported in the national accounts, government and balance of payment statistics. As mentioned earlier, in the case of Mozambique, we draw on DNPO government finance statistics and IMF balance of payment statistics.

The SAM contains a number of factors of production, which earn incomes from their use in the production process, and then pay their incomes to enterprises, households, government and the rest of the world. Indirect capital earnings or enterprise profits are taxed according to average corporate tax rates and some profits may be repatriated abroad. The remaining capital earnings, together with labour earnings are paid to households. Households use their incomes to pay taxes, make transfers, save, and consume domestically produced and imported commodities.

\footnotetext{
${ }^{1}$ For general discussions of SAMs and SAM-based modelling, see Breisinger et al. (2009), Pyatt and Round (1985), Pyatt (1988), Reinert and Roland-Holst (1997), and Robinson and Roland-Holst (1988).
} 


\section{Constructing the SAM}

The initial task in building a SAM involves compiling data from various sources into the SAM framework. For Mozambique, this information was drawn from unpublished 2015 INE data together with DNPO government finance statistics, IMF balance of payment statistics, and other selected data from the 2007 SAM (Arndt and Thurlow 2014).

The INE unpublished industry-level production accounts, commodity-level supply-demand balances, and a Supply Matrix for 2015 are consistent with each other (barring some rounding difference). The government finance and balance of payment data other than the INE data involves macro accounts and do not require adjustment elsewhere in the SAM. Where they overlap with the INE data, the latter is used. The use matrix taken from the 2007 SAM (Arndt and Thurlow 2014) is fitted to the INE activities' intermediate use data and their commodities' intermediate sales estimates using biproportional scaling. The use matrix had to be subjected to minor manual adjustment to ensure a solution to this scaling. 
Table 2: A 2015 Macro SAM for Mozambique (Millions of Meticals)

\begin{tabular}{|c|c|c|c|c|c|c|c|c|c|c|c|c|c|c|c|c|}
\hline & Activities & $\begin{array}{c}\text { Commoditi } \\
\text { es }\end{array}$ & Land & Labour & Capital & Enterprises & Households & Government & $\begin{array}{c}\text { Net activity } \\
\text { taxes }\end{array}$ & $\begin{array}{l}\text { Net product } \\
\text { taxes }\end{array}$ & Import duties & Income taxes & $\begin{array}{l}\text { Changes in } \\
\text { inventories }\end{array}$ & Accumulation & $\begin{array}{l}\text { Rest of the } \\
\text { world }\end{array}$ & $\overline{\text { Total }}$ \\
\hline Activities & & 893,356 & & & & & 110,962 & & & & & & & & & $1,004,318$ \\
\hline Commodities & 465,535 & 124,546 & & & & & 290,059 & 157,807 & & & & & 79,092 & 189,089 & 190,616 & $1,496,745$ \\
\hline Land & 19,337 & & & & & & & & & & & & & & & 19,337 \\
\hline Labour & 321,613 & & & & & & & & & & & & & & 2,100 & 323,713 \\
\hline Capital & 197,833 & & & & & & & & & & & & & & 2,205 & 200,038 \\
\hline Enterprises & & & & & 183,440 & & & 5,083 & & & & & & & 11,871 & 200,394 \\
\hline Households & & & 19,337 & 321,633 & & 121,716 & & 15,962 & & & & & & & 5,386 & 484,034 \\
\hline Government & & & & & 5,810 & 17,329 & & 3,494 & & 42,668 & 10,227 & 62,621 & & & 20,678 & 162,828 \\
\hline Net activity taxes & & & & & & & & & & & & & & & & 0 \\
\hline Net product taxes & & 42,668 & & & & & & & & & & & & & & 42,668 \\
\hline Import duties & & 10,227 & & & & & & & & & & & & & & 10,227 \\
\hline Income taxes & & & & & & 41,310 & 21,311 & & & & & & & & & 62,621 \\
\hline $\begin{array}{l}\text { Changes in } \\
\text { inventories }\end{array}$ & & & & & & & & & & & & & & 79,092 & & 79,092 \\
\hline Accumulation & & & & & & 20,039 & 61,701 & $-23,809$ & & & & & & & 210,250 & 268,182 \\
\hline Rest of the world & & 425,947 & & 2,081 & 10,788 & 0 & & 4,291 & & & & & & & & 443,107 \\
\hline Total & $1,004,318$ & $1,496,745$ & 19,337 & 323,713 & 200,038 & 200,394 & 484,034 & 162,828 & 0 & 42,668 & 10,227 & 62,621 & 79,092 & 268,182 & 443,107 & \\
\hline
\end{tabular}

Source: Authors' own calculations. 
Household income and expenditure data and labour force data (earnings by activity and level of education attainment) are available from unpublished household and labour market survey data for 2014-15 (INE 2015), the data that was processed in the same way as for the 2007 SAM (Arndt and Thurlow 2014) and the 2012 SAM (van Seventer 2015).

The Macro SAM shown in Table 2 is an aggregation of the more detailed micro SAM. The rest of this section explains how each macro SAM entry is derived and disaggregated. Each entry in the SAM is in turn discussed below. The notation for SAM entries is (row, column) and the values are in millions of 2015 Meticals. The final disaggregated SAM is included in the accompanying Excel workbook. $^{2}$

i (Commodities, Activities)...MTmill465,535

Intermediate consumption. The total for each industry is available from unpublished INE industry production accounts. A breakdown by commodity is based on a use matrix adapted from the 2007 SAM (Arndt and Thurlow 2014).

ii (Land, Activities)...MTmill19,337

Compensation for land use. Part of gross value added with the latter available from unpublished INE industry production accounts. Compensation for land use applies to agricultural crop activities and is based on the authors' assumption of around $1 / 5$ share of the total agricultural crop value added. The rest is allocated to labour and capital components of value added (explained in iii below). For individual agricultural crop activities, an initial share of land-use value is taken from the 2007 SAM (Arndt and Thurlow 2014), followed by a biproportional scaling routine to ensure that lower level control totals are consistent with the wage share of value added for the total of all agricultural crop activities (see discussion below).

iii (Labor, Activities)...MTmill321,613

Compensation of employees. Part of gross value added with the latter available from unpublished INE industry production accounts. The share of labor in economy-wide value added is based on the INE's remunerations on employees plus a share of mixed income. The latter corresponds to 45 per cent of INE's total gross operating surplus (from which the land use value (see ii) is subtracted). The mixed income share is based on historical data from INE and on the authors' assumptions. The remaining 55 per cent corresponds to the share of capital in INE's total gross operating surplus (to be used in iv below). The share of labor in total agricultural crop value added is estimated using the average shares used in the 1994-1995 SAM (Arndt et al. 1998) and the 2007 SAM (Arndt and Thurlow 2014). For individual agricultural crop activities, an initial share of land-use value is taken from the 2007 SAM (Arndt and Thurlow 2014). Total wage earnings for non-crop (including non-agricultural) activities can be derived by taking the difference between economy-wide total wage earnings and wage earnings for crop activities. The initial breakdown of non-crop wage earnings is based on additional unpublished INE data for wage earnings by activity. For both crop and non-crop activities a separate

\footnotetext{
${ }^{2}$ Excel workbook is available at https://www.wider.unu.edu/sites/default/files/Data/Data-for-a-2015-

Mozambique-SAM-v2018.xlsx.
} 
biproportional scaling routine is used to ensure that the lower level control totals were met.

Gross operating surplus [net operating surplus + consumption of fixed capital (depreciation)]. Part of gross value added with the latter available from unpublished INE industry production accounts. The shares of gross operating surplus in gross value added for total crop and total non-crop (including non-agricultural) activities can be derived as a residual from ii and iii above. The same residual approach applies to detailed crop and non-crop activities.

(Activities, Commodities)...MTmill891,486

Marketed output of total domestic economy. Available from unpublished INE industry production accounts and commodity supply accounts, including the distribution across activity and commodity. The data is presented so that activities make homogeneous commodities, characterized by a diagonal domestic marketed supply matrix.

(Commodities, Commodities)...MTmill124,546

Transaction margins. Available from unpublished INE commodity supply-demand balance accounts, including the distribution across commodities. Adjusted by the crossentropy estimation method (see Section 4 below).

vii (Net product taxes, Commodities)...MTmill42,668

Taxes on products. Available from unpublished INE commodity supply-demand balance accounts, including the distribution across commodities.

viii (Import duties, Commodities)...MT'Tmill10,227

Import duties. Available from unpublished INE commodity supply-demand balance accounts, including the distribution across commodities.

ix (Rest of the world, Commodities)...MTmill425,947

Imports of goods and services. Available from unpublished INE commodity supplydemand balance accounts.

(Households, Land)...MTmill19,337

Household earnings from land holdings. Is equal to compensation for land use. All income is allocated to households and a breakdown into household categories is based on the 2008-09 Household Survey (INE 2009). The 2014-15 Household Survey did not report this data.

Compensation of residents. Is calculated as compensation of employees plus remittances from workers abroad less remittances to non-resident workers. A breakdown of earnings into labor categories and household income groups is based on the 2014-15 Household 
Survey (INE, 2015). The labour category shares are also applied to remittances from workers abroad.

xii (Rest of the world, Labor)...MTmill2,081

Remittances to non-resident workers. Available from IMF Balance of Payments statistics (primary income flows). It is assumed that these remittance outflows only apply to the highest skilled labour category

xiii (Enterprises, Capital)...MTmill183,440

Gross operating surplus of corporations. Derived as a residual by subtracting net primary income outflows and property income of the government from total gross operating surplus. Net primary income outflows are available from the IMF Balance of Payment statistics and property income received by the government is available from the DNPO government statistics. Not shown here is that a portion of this amount (MTmill 6,552) is transferred directly to households (in the Macro SAM cell below). This is in lieu of income from the production factor 'livestock', which will have its own account in the Micro SAM.

xiv (Government, Capital)...MTmill5,810

Property income of the government. Available from DNPO Government Finance statistics.

(Rest of the world, Capital)...MTmill10,788

Investment income outflows. Available from IMF Balance of Payments statistics (primary income flows)

xvi (Households, Enterprises)...MTmill121,716

Property and investment income received by households. Derived as a residual by netting enterprise transfers to- and from the government and the rest of the world (for details, see below), corporate tax and savings out from the transfer of gross operating surplus to enterprises. A breakdown into household categories is based on the distribution of enterprise income to households according to the 2008-09 Household Survey (INE 2009). Not shown here is that a portion of this amount (MTmill 6,552) is transferred directly to households (in the Macro SAM cell to the left). This is in lieu of income from the production factor 'livestock', which will have its own account in the Micro SAM.

xvii (Government, Enterprises)...MTmill17,329

Miscellaneous transfers by enterprises to government. Available from DNPO Government Finance statistics (non-fiscal revenue $=$ receitas não fiscais, earmarked revenue $=$ receitas consignadas)

xviii (Income taxes, Enterprises)...MTmill41,310

Corporate tax. Available from DNPO Government Finance statistics

xix (Accumulation, Enterprises)...MTmill20,039 
Corporate savings. Assumed to be 10per cent of total revenue

$\mathrm{xx}$

$\mathrm{xxi}$

xxii

xxiii

xxiv

$\mathrm{XXV}$

xxvi

Government transfers to enterprises. Available from DNPO Government Finance statistics (domestic public debt servicing (interest) $=$ encargos da dívida pública interna (juros))

xxvii (Households, Government)...MTmill15,962

Government transfers to households. Available from DNPO Government Finance statistics (current transfers $=$ transferências correntes, households $=$ famílias). A 
breakdown across household categories is based on the 2014-15 Household Survey (INE, 2015).

xxviii (Government, Government)...MTmill3,494

Government transfers to other government units (can be netted out). Available from DNPO Government Finance statistics (current transfers = transferências correntes, for public administration $=$ para a administração pública)

xxix (Accumulation, Government)...MTmill-23,809

Government budget deficit. Derived as a residual of government revenues and expenditures

xxx (Rest of the world, Government)...MTmill4,291

Government transfers to the rest of the world. Available from the DNPO Government Finance statistics [Current transfers abroad $=$ Transferências correntes externas, external public debt servicing (interest) = encargos da dívida pública externa (juros)]

xxxi (Government, Net product taxes)...MTmill42,668

Sales tax collected and transferred to the government. Derived from elsewhere in the SAM (see vii above)

xxxii (Government, Import duties)...MTmill10,227

Import duties collected and transferred to the government. Derived from elsewhere in the SAM (see viii above)

xxxiii (Government, Income taxes)...MTmill62,621

Income and corporate tax collected and transferred to the government. Derived from elsewhere in the SAM (see xviii and xxiii above)

xxxiv (Commodities, Changes in inventories)...MTmill79,092

Change in inventories. Available from unpublished INE commodity supply-demand balance accounts, including the distribution across commodities.

xxxv (Commodities, Accumulation)...MT'Tmill189,089

Gross fixed capital formation. Available from unpublished INE commodity supplydemand balance accounts, including the distribution across commodities.

xxxvi (Changes in inventories, Accumulation)...MTmill79,092

Change in inventories. Derived from elsewhere in the SAM and transferred to the accumulation account (see xxxiv above). 
xxxvii (Commodities, Rest of the world)...MTmill190,616

Exports of goods and services. Available from unpublished INE commodity supplydemand balance accounts, including the distribution across commodities. Some manual adjustment had to be undertaken in order to avoid exports being larger than domestic supply. In particular this is a problem for the commodities "tobacco leaf" and for "other mining". In the case of tobacco leaf, some exports were reallocated to beverages and manufactured tobacco while some other mining exports were shifted to coal.

xxxviii (Labor, Rest of the world)...MTmill2,100

Primary income, compensation of employees residing in the rest of the world. Available from IMF Balance of Payments statistics (primary income flows). The distribution across labour categories is based on total earnings shares extracted from the 2014-15 Household Survey (INE, 2015).

xxxix (Capital, Rest of the world)...MTmill2,205

Primary income, investment income from the rest of the world. Available from IMF Balance of Payments statistics (primary income flows)

$\mathrm{xl} \quad$ (Enterprises, Rest of the world)...MTmill11,871

Current transfers from the rest of the world to enterprises. Available from IMF Balance of Payments statistics

xli (Households, Rest of the world)...MTmill5,386

Current transfers from the rest of the world to households. Available from IMF Balance of Payments statistics (Other current transfers). A further breakdown into households is based on the 2014-15 Household Survey (INE 2015)

xlii (Government, Rest of the world)...MTmill20,678

Current transfers from the rest of the world to government. Available from IMF Balance of Payments statistics

xliii (Accumulation, Rest of the world)...MTmill210,250

Balance on the current account. Derived as a residual of receipts from and payments to the rest of the world

\section{$4 \quad$ Finalizing the SAM}

Finalizing the SAM takes places in two stages. First, a detailed SAM is constructed that contains aggregate entries for factors and households (labelled here as the SUTSAM). As mentioned at the start of the previous section, the core data of this SUTSAM is derived from INE's unpublished industry-level production accounts, commodity-level supply-demand balances and a supply matrix for 2015. Aggregation of these data sources to SAM commodities and activities is reported in Appendix A. These data source are consistent with each other. 
The DNPO government finance and the IMF balance of payment data other than the INE data mentioned above involves macro accounts with internal residuals calculated in the Macro SAM. They therefore do not require adjustments elsewhere in the SUTSAM. Where they overlap with INE data such as with total government expenditure on goods and services and total indirect taxes on goods and services, the INE data is used. The use matrix taken from the 2007 SAM (Arndt and Thurlow 2014) is fitted to INE's activities' intermediate use estimates and their commodities' intermediate sales estimates, using biproportional scaling. The use matrix had to undergo minor manual adjustment to ensure a solution to this scaling.

In order to complete the SUTSAM, errors were resolved using the Cross-Entropy Estimation method as described by Robinson et al. (2001). The method has been set up such that the Macro SAM entries of Table 2 are preserved.

In a second stage, the SUTSAM, is disaggregated across factors and households using the 2014 15 Household Survey data [INE 2015 with some shares also taken from the 2008-09 Household Survey (INE 2009)]. Since the aggregate SUTSAM is balanced, this can be set up such that it results in imbalances for the household accounts only. These household accounts were balanced by biproportional scaling of the income distribution submatrix of the SAM. All sources of household income and household expenditure were initially disaggregated using the 2014-15 Household Survey data [INE 2015 with some shares also taken from the 2008-09 Household Survey (INE 2009)]. The resulting total income was compared with the total outlays of each household. Adjustments were made by scaling across the income sources while the target household income/expenditure total for the final balanced SAM was set to be the household outlay totals. Imbalances were therefore eliminated while holding all other non-household-related entries of the SUTSAM constant.

Finally, all operating surplus payments by the three livestock industries are reallocated to a newly created production factor 'livestock'. The receipts by the livestock production factor account are paid directly to households according to the relevant shares in the underlying 2008-09 Household Survey. These receipts are subtracted from the payments by capital to enterprises and by enterprises to households. In that way, no rebalancing is required.

\section{$5 \quad$ Data issues}

While the SAM construction described above can be considered as the acceptable given the data sources at hand, a number of improvements can be considered. They are:

1. The reallocation of mixed income from gross operating surplus to labour and land is based on the best judgment from the authors described in section 3ii above, as has happened in the past. While INE is not publishing this detail, further research is required to arrive at sound criteria based estimates.

2. The 2015 SAM is using government expenditure and revenues from INE's unpublished data combined with DNPO data. Due to timing of data releases, the latest government revenue information from the 2015 State General Account (Government of Mozambique 2016) could not be incorporated in INE's unpublished data.

3. The use matrix is at this stage derived from the 2007 SAM (Arndt and Thurlow 2014). Earlier, we mentioned that we had to make several manual adjustments in order to fit this use matrix to the INE industry and commodity-level intermediate use and sales respectively. Moreover, the origin of the use matrix dates back well into the 1990s (Arndt et al. 1998). It is recommended that recent enterprise surveys and other sources (including 
case studies for selected crops in agriculture) are explored in order to construct a new use matrix.

4. Land, livestock, and enterprise income distribution to households was not available from the 2014-15 Household Survey and were based on shares from the 2008-09 Household Survey (INE 2009), (see discussion in 3x and 3xvi above). For the same reason, the distribution of household income tax payments and outlays of savings were modelled (see discussion in 3xxiii and 3xxiv above). It is recommended that the next household survey makes an attempt to capture these earnings in the better way.

\section{Summary}

This paper documented a 2015 Social Accounting Matrix (SAM) for Mozambique. The SAM is built using INE unpublished industry-level production accounts, commodity-level supply-demand balances and a Supply Matrix, together with National Accounts, DNPO government and IMF balance of payment statistics, all for the year 2015. Household and labour market survey data for 2014-15 (INE 2015) are used for further detail as well as a use matrix from a 2007 SAM for Mozambique (Arndt and Thurlow 2014).

It offers a detailed representation of the Mozambican economy and identifies 55 activities and commodities. Labour is disaggregated by education attainment level, and household income and expenditure by per capita expenditure quintiles both for urban and rural areas. The SAM features production for home consumption as reported in the unpublished data made available by INE and identifies government, investment and foreign accounts.

The core data for the SAM uses INE unpublished industry-level production accounts, commoditylevel supply-demand balances and a supply matrix together with national accounts. While the SAM construction described above can be considered as acceptable given the data sources at hand, a number of improvements can be considered. They could focus on:

1. criteria-based estimates of the mixed income shares in gross operating surplus and land use values for agriculture crop activities;

2. incorporating the latest government revenue data in INE's unpublished activity and commodity accounts;

3. updating the use matrix using enterprise surveys;

4. including details for some components of household income and outlays that were not available from the 2014-15 Household Survey (INE 2015) in the next household survey. 


\section{References}

Arndt, C., and J. Thurlow (2014). 'A 2007 Social Accounting Matrix (SAM) for Mozambique'. Washington DC: International Food Policy Research Institute (IFPRI). Available at: http:// ebrary.ifpri.org/utils/getfile/collection/p15738coll2/id/128888/filename/129099.p df

Arndt, C., A. Cruz, H. Tarp Jensen, S. Robinson, and F. Tarp (1998). 'Social accounting matrices for Mozambique, 1994 and 1995', IFPRI TMD Working Paper 28. Washington DC: International Food Policy Research Institute. Available at: http://www.ifpri.org/ publication/social-accounting-matrices-mozambique-1994-and-1995.

Breisinger, C., M. Thomas and J. Thurlow (2009). 'Social Accounting Matrices and Multiplier Analysis: An Introduction with Exercises', Food Security in Practice Technical Guide 5. Washington DC: International Food Policy Research Institute (IFPRI). Available at: http://www.ifpri.org/sites/default/files/publications/sp5.pdf.

DNPO, Mapa Fiscal, (2017). Maputo: National Directorate of Planning and Budget, Fiscal Tables, March.

INE (Instituto Nacional de Estatística) (2009). 'Inquérito ao Orçamento Familiar 2008/09 (IOF08)'. Maputo: Instituto Nacional de Estatística.

INE (Instituto Nacional de Estatística) (2014). 'Statistical Yearbook 2013 (Anuario Estatistico)'. Maputo: Instituto Nacional de Estatística.

INE (Instituto Nacional de Estatística) (2015). 'Inquérito aos Orçamentos Familiares (IOF) 20142015 - I $^{\circ}$ Trimestre'. Maputo: Instituto Nacional de Estatística. Available at: http://www.ine.gov.mz/operacoes-estatisticas/inqueritos/inquerito-sobre-orcamentofamiliar/inquerito-aos-orcamentos-familiares-iof-2014-2015-2013-io-trimestre/view.

INE (Instituto Nacional de Estatística) (2016). 'Statistical Yearbook 2015 (Anuario Estatistico)'. Maputo: Instituto Nacional de Estatística.

IMF Balance of Payment Statistics. Available at: http://data.imf.org/?sk=b4a9517a-a080-4d8ab1dd-d1bba58213b7\&sId=1390030109571. Washington D.C.: International Monetary Fund.

Pyatt, G. (1988). 'A SAM Approach to Modelling', Journal of Policy Modelling, 10(3): 327-52.

Pyatt, G., and J. Round (1985). 'Social Accounting Matrices: a Basis for Planning'. Washington DC: World Bank.

Reinert, K.A., and D.W. Roland-Holst (1997). 'Social Accounting Matrices', in J.F. Francois and K.A. Reinert (eds) Applied Methods for Trade Policy Analysis: A Handbook. New York: Cambridge University Press.

Robinson, S., A. Cattaneo, and M. El-Said (2001). "Updating and Estimating a Social Accounting Matrix Using Cross Entropy Methods”, Economic Systems Research, 13(1), 47-64.

Robinson, S., and D.W. Roland-Holst (1988). 'Macroeconomic Structure and Computable General Equilibrium Models', Journal of Policy Modelling, 10(3): 353-75.

van Seventer, D.E.N. (2015). A 2012 Social Accounting Matrix (SAM) for Mozambique. Helsinki: UNU-WIDER. Available at: https://www.wider.unu.edu/database/2012-socialaccounting-matrix-mozambique. 


\section{Appendix A: Mapping from INE to SAM Activity and Commodity}

\begin{tabular}{|c|c|c|c|c|c|c|}
\hline & $\begin{array}{l}\text { SAM } \\
\text { Code }\end{array}$ & SAM Description & $\begin{array}{l}\text { INE } \\
\text { Activity } \\
\text { Code }\end{array}$ & INE Activity Description & $\begin{array}{l}\text { INE } \\
\text { Commodity } \\
\text { Code }\end{array}$ & INE Commodity Description \\
\hline 1. & ocer & Other cereals & R011 & Agricultura & P01111-1 & Trigo \\
\hline 2. & maiz & Maize & R011 & Agricultura & P01111-2 & Milho \\
\hline 3. & sorg & Sorghum and millet & R011 & Agricultura & P01111-9 & Mapira, mexoeira e outro cereais em grão \\
\hline 4. & puls & Pulses & R011 & Agricultura & P01112-1 & Feijão \\
\hline 5. & gnut & Groundnuts & R011 & Agricultura & P01112-2 & Amendoim \\
\hline 6. & rice & Rice & R011 & Agricultura & P01120 & Arroz em casca \\
\hline 7. & cass & Cassava & R011 & Agricultura & P01131 & Mandioca \\
\hline 8. & root & Other roots & R011 & Agricultura & P01139-1 & Outros tubérculos e raízes \\
\hline 9. & vege & Vegetables & R011 & Agricultura & P01139-2 & Produtos hortícolas \\
\hline 10. & sugr & Sugar cane & R011 & Agricultura & P01140 & Cana de açúcar \\
\hline 11. & toba & Tobacco & R011 & Agricultura & P01150 & Tabaco-folha \\
\hline 12. & cott & Cotton and fibres & R011 & Agricultura & P01161 & Algodão-caroço \\
\hline 13. & frui & Fruits and nuts & R011 & Agricultura & P01200 & Frutos frescos \\
\hline 14. & frui & Fruits and nuts & R011 & Agricultura & P01231 & Cajú \\
\hline 15. & oils & Other oilseeds & R011 & Agricultura & P01240-1 & Copra e coco \\
\hline 16. & ocrp & Other crops & R011 & Agricultura & P01240-9 & Jatrofa \\
\hline 17. & coff & Coffee and tea & R011 & Agricultura & P01251 & Chá-folha \\
\hline 18. & ocrp & Other crops & R011 & Agricultura & P01291 & $\begin{array}{l}\text { Outros produtos agrícolas de uso } \\
\text { industrial }\end{array}$ \\
\hline 19. & ocrp & Other crops & R011 & Agricultura & P01292 & Outros produtos agrícolas não industriais \\
\hline 20. & catt & Cattle & R014 & Produção animal & P01410 & Gado bovino \\
\hline 21. & oliv & Other livestock & R014 & Produção animal & P01420 & Gado ovino e caprino \\
\hline 22. & oliv & Other livestock & R014 & Produção animal & P01430 & Gado suíno \\
\hline 23. & poul & Poultry & R014 & Produção animal & P01440-1 & Aves vivas \\
\hline 24. & poul & Poultry & R014 & Produção animal & P01440-2 & Ovos frescos \\
\hline 25. & oliv & Other livestock & R014 & Produção animal & P01499-1 & Animais selvagens e outros comestíveis \\
\hline 26. & oliv & Other livestock & R014 & Produção animal & P01499-9 & Produtos de origem animal \\
\hline 27. & fore & Forestry & R020 & $\begin{array}{l}\text { Silvicultura, exploração florestal e } \\
\text { actividades relacionadas }\end{array}$ & P02200-1 & Lenha e carvão vegetal \\
\hline 28. & fore & Forestry & R020 & $\begin{array}{l}\text { Silvicultura, exploração florestal e } \\
\text { actividades relacionadas }\end{array}$ & P02200-2 & $\begin{array}{l}\text { Madeira em toros e outros produtos da } \\
\text { silvicultura }\end{array}$ \\
\hline
\end{tabular}




\begin{tabular}{|c|c|c|c|c|c|c|}
\hline & $\begin{array}{l}\text { SAM } \\
\text { Code }\end{array}$ & SAM Description & $\begin{array}{l}\text { INE } \\
\text { Activity } \\
\text { Code }\end{array}$ & INE Activity Description & $\begin{array}{l}\text { INE } \\
\text { Commodity } \\
\text { Code }\end{array}$ & INE Commodity Description \\
\hline 29. & fore & Forestry & R020 & $\begin{array}{l}\text { Silvicultura, exploração florestal e } \\
\text { actividades relacionadas }\end{array}$ & P02300 & $\begin{array}{l}\text { Outros produtos florestais, excepto } \\
\text { madeira }\end{array}$ \\
\hline 30. & fish & Fishing & R030 & $\begin{array}{l}\text { Pesca, aquacultura, e actividades dos } \\
\text { serviços relacionados }\end{array}$ & P03111-1 & Peixes frescos, refrigerados \\
\hline 31. & fish & Fishing & R030 & $\begin{array}{l}\text { Pesca, aquacultura, e actividades dos } \\
\text { serviços relacionados }\end{array}$ & P03111-2 & Camarão, gamba e lagosta \\
\hline 32. & fish & Fishing & R030 & $\begin{array}{l}\text { Pesca, aquacultura, e actividades dos } \\
\text { serviços relacionados }\end{array}$ & P03111-3 & Outros produtos da pesca \\
\hline 33. & coal & Coal and lignite & R051 & Extracção de carvão & P05100 & Carvão mineral \\
\hline 34. & ngas & Natural gas & $\mathrm{R} 062$ & $\begin{array}{l}\text { Extracção de gás natural e } \\
\text { condensados }\end{array}$ & P06201 & $\begin{array}{l}\text { Gás natural, liquefeito ou no estado } \\
\text { gasoso }\end{array}$ \\
\hline 35. & ngas & Natural gas & $\mathrm{R} 062$ & $\begin{array}{l}\text { Extracção de gás natural e } \\
\text { condensados }\end{array}$ & P06202 & Condensados de gás natural \\
\hline 36. & omin & Other mining & $\mathrm{R} 070$ & $\begin{array}{l}\text { Extracção e preparação de de } \\
\text { minérios metálicos }\end{array}$ & P07291 & Bauxite \\
\hline 37. & omin & Other mining & $\mathrm{R} 070$ & $\begin{array}{l}\text { Extracção e preparação de de } \\
\text { minérios metálicos }\end{array}$ & P07299 & Outros minerais metálicos \\
\hline 38. & omin & Other mining & R080 & Outras indústrias extrativas & P08100 & Pedra, argila e areia \\
\hline 39. & omin & Other mining & R080 & Outras indústrias extrativas & P08991 & Pedras preciosas e semi-preciosas \\
\hline 40. & omin & Other mining & R080 & Outras indústrias extrativas & P08999 & Outros minerais não metálicos \\
\hline 41. & meat & Meat & R101 & $\begin{array}{l}\text { Abate de animais, preparacao e } \\
\text { conservaçao de carne e de produtos a } \\
\text { base de carne }\end{array}$ & P10101-1 & Carne de bovino \\
\hline 42. & meat & Meat & R101 & $\begin{array}{l}\text { Abate de animais, preparacao e } \\
\text { conservaçao de carne e de produtos a } \\
\text { base de carne }\end{array}$ & P10101-2 & Carne de suino \\
\hline 43. & meat & Meat & R101 & $\begin{array}{l}\text { Abate de animais, preparacao e } \\
\text { conservaçao de carne e de produtos a } \\
\text { base de carne }\end{array}$ & P10101-3 & $\begin{array}{l}\text { Carne de outros animais domesticados, } \\
\text { excepto aves }\end{array}$ \\
\hline 44. & meat & Meat & R101 & $\begin{array}{l}\text { Abate de animais, preparacao e } \\
\text { conservaçao de carne e de produtos a } \\
\text { base de carne }\end{array}$ & P10101-8 & Peles e couro \\
\hline
\end{tabular}




\begin{tabular}{|c|c|c|c|c|c|c|}
\hline & $\begin{array}{l}\text { SAM } \\
\text { Code }\end{array}$ & SAM Description & $\begin{array}{l}\text { NE Ac } \\
\text { Code }\end{array}$ & NE Activity Description & nmodity Code & INE Commodity Description \\
\hline 45. & meat & Meat & R101 & $\begin{array}{l}\text { Abate de animais, preparacao e } \\
\text { conservaçao de carne e de produtos a } \\
\text { base de carne }\end{array}$ & P10102 & Carne de aves \\
\hline 46. & meat & Meat & R101 & $\begin{array}{l}\text { Abate de animais, preparacao e } \\
\text { conservaçao de carne e de produtos a } \\
\text { base de carne }\end{array}$ & P10104 & Produtos a base de carne \\
\hline 47. & food & Other foods & R107 & $\begin{array}{l}\text { Fabricação de outros produtos } \\
\text { alimentares diversos, n.e. }\end{array}$ & P10200 & $\begin{array}{l}\text { Produtos da pesca preparados e em } \\
\text { conserva }\end{array}$ \\
\hline 48. & food & Other foods & R107 & $\begin{array}{l}\text { Fabricação de outros produtos } \\
\text { alimentares diversos, n.e. }\end{array}$ & P10301 & $\begin{array}{l}\text { Frutos e produtos vegetais } \\
\text { transformados incl sumos }\end{array}$ \\
\hline 49. & food & Other foods & R107 & $\begin{array}{l}\text { Fabricação de outros produtos } \\
\text { alimentares diversos, n.e. }\end{array}$ & P10302 & Amêndoa de cajú inteira e partida \\
\hline 50. & food & Other foods & R107 & $\begin{array}{l}\text { Fabricação de outros produtos } \\
\text { alimentares diversos, n.e. }\end{array}$ & P10400 & Óleos vegetais e animais \\
\hline 51. & food & Other foods & R107 & $\begin{array}{l}\text { Fabricação de outros produtos } \\
\text { alimentares diversos, n.e. }\end{array}$ & P10500 & Leite processado e derivados \\
\hline 52. & cvgp & $\begin{array}{l}\text { Cereal and vegetable } \\
\text { processing }\end{array}$ & R106 & $\begin{array}{l}\text { Transformação de cereais e } \\
\text { leguminosas; fabricação de rações }\end{array}$ & P10611-1 & Farinha de trigo \\
\hline 53. & cvgp & $\begin{array}{l}\text { Cereal and vegetable } \\
\text { processing }\end{array}$ & R106 & $\begin{array}{l}\text { Transformação de cereais e } \\
\text { leguminosas; fabricação de rações }\end{array}$ & P10611-2 & Farinha de milho \\
\hline 54. & cvgp & $\begin{array}{l}\text { Cereal and vegetable } \\
\text { processing }\end{array}$ & R106 & $\begin{array}{l}\text { Transformação de cereais e } \\
\text { leguminosas; fabricação de rações }\end{array}$ & P10612 & $\begin{array}{l}\text { Farinha de mandioca e derivados, } \\
\text { inclui tapioca }\end{array}$ \\
\hline 55. & cvgp & $\begin{array}{l}\text { Cereal and vegetable } \\
\text { processing }\end{array}$ & R106 & $\begin{array}{l}\text { Transformação de cereais e } \\
\text { leguminosas; fabricação de rações }\end{array}$ & P10613 & Arroz descascado \\
\hline 56. & cvgp & $\begin{array}{l}\text { Cereal and vegetable } \\
\text { processing }\end{array}$ & R106 & $\begin{array}{l}\text { Transformação de cereais e } \\
\text { leguminosas; fabricação de rações }\end{array}$ & P10619 & $\begin{array}{l}\text { Outros produtos e serviços de } \\
\text { moagem }\end{array}$ \\
\hline 57. & food & Other foods & R107 & $\begin{array}{l}\text { Fabricação de outros produtos } \\
\text { alimentares diversos, n.e. }\end{array}$ & P10710 & Pão, e produtos de pastelaria e doçaria \\
\hline 58. & food & Other foods & R107 & $\begin{array}{l}\text { Fabricação de outros produtos } \\
\text { alimentares diversos, n.e. }\end{array}$ & P10730 & Açúcar e Melaço de açúcar \\
\hline 59. & food & Other foods & R107 & $\begin{array}{l}\text { Fabricação de outros produtos } \\
\text { alimentares diversos, n.e. }\end{array}$ & P10750 & Massas alimentícias \\
\hline 60. & food & Other foods & R107 & $\begin{array}{l}\text { Fabricação de outros produtos } \\
\text { alimentares diversos, n.e. }\end{array}$ & P10790 & $\begin{array}{l}\text { Outros produtos das indústrias } \\
\text { alimentícias }\end{array}$ \\
\hline 61. & cvgp & $\begin{array}{l}\text { Cereal and vegetable } \\
\text { processing }\end{array}$ & R106 & $\begin{array}{l}\text { Transformação de cereais e } \\
\text { leguminosas; fabricação de rações }\end{array}$ & P10800 & Rações \\
\hline 62. & beve & Beverage \& tobacco mnf & $\mathrm{R} 110$ & Fabricação de bebidas e tabaco & P11010-1 & $\begin{array}{l}\text { Aguardentes e outras bebidas } \\
\text { espirituosas }\end{array}$ \\
\hline 63. & beve & Beverage \& tobacco mnf & $\mathrm{R} 110$ & Fabricação de bebidas e tabaco & P11010-2 & Bebidas alcóolicas tradicionais \\
\hline 64. & beve & Beverage \& tobacco mnf & R110 & Fabricação de bebidas e tabaco & P11020 & Vinho \\
\hline 65. & beve & Beverage \& tobacco mnf & $\mathrm{R} 110$ & Fabricação de bebidas e tabaco & P11030 & Cerveja e malte \\
\hline
\end{tabular}




\begin{tabular}{|c|c|c|c|c|c|c|}
\hline \multicolumn{7}{|c|}{ Appendix A (cont): Mapping from INE to SAM Activity and Commodity } \\
\hline 66. & beve & Beverage \& tobacco $\mathrm{mnf}$ & R110 & Fabricação de bebidas e tabaco & P11041 & $\begin{array}{l}\text { Águas minerais e bebidas refrigerantes } \\
\text { não alcoólicas }\end{array}$ \\
\hline 67. & ptob & Beverage \& tobacco $\mathrm{mnf}$ & R110 & Fabricação de bebidas e tabaco & P12002 & Cigarros, de charutos e similares \\
\hline 68. & text & Textiles & R130 & Fabricação de artigos têxteis e vestuário & P13111-1 & Fibra de algodão \\
\hline 69. & text & Textiles & R130 & Fabricação de artigos têxteis e vestuário & P13111-2 & Outros produtos de fiação \\
\hline 70. & text & Textiles & R130 & Fabricação de artigos têxteis e vestuário & P13900 & Produtos têxteis, malhas e tapecaria \\
\hline 71. & clth & Clothing & R130 & Fabricação de artigos têxteis e vestuário & P14100 & Vestuário, excepto de plástico \\
\hline 72. & leat & Leather and footwear & R150 & Preparação de couro e artigos de couro & P15000 & Curtumes, calçado e artigos de couro \\
\hline 73. & wood & Wood and paper & R160 & $\begin{array}{l}\text { Industria de madeira e da cortica } \\
\text { excepto mobiliario }\end{array}$ & P16000 & $\begin{array}{l}\text { Produtos da serração de madeira, } \\
\text { folhados e contraplacados, carpintaria }\end{array}$ \\
\hline 74. & wood & Wood and paper & $\mathrm{R} 170$ & Produção de papel e impressão & P17000 & Papel e artigos de papel e cartão \\
\hline 75. & wood & Wood and paper & $\mathrm{R} 170$ & Produção de papel e impressão & P18100 & Impressão \\
\hline 76. & petr & Petroleum & R200 & $\begin{array}{l}\text { Fabricação de produtos quimicos, } \\
\text { plásticos e de borracha }\end{array}$ & P19200-1 & Gasolina \\
\hline 77. & petr & Petroleum & R200 & $\begin{array}{l}\text { Fabricação de produtos quimicos, } \\
\text { plásticos e de borracha }\end{array}$ & P19200-2 & Gasóleo \\
\hline 78. & petr & Petroleum & R200 & $\begin{array}{l}\text { Fabricação de produtos quimicos, } \\
\text { plásticos e de borracha }\end{array}$ & P19200-3 & $\begin{array}{l}\text { Outros combústíveis derivados do } \\
\text { petróleo }\end{array}$ \\
\hline 79. & petr & Petroleum & R200 & $\begin{array}{l}\text { Fabricação de produtos quimicos, } \\
\text { plásticos e de borracha }\end{array}$ & P19200-9 & $\begin{array}{l}\text { Óleos e massas lubrificantes, inclui } \\
\text { betume }\end{array}$ \\
\hline 80. & chem & Chemicals & R200 & $\begin{array}{l}\text { Fabricação de produtos quimicos, } \\
\text { plásticos e de borracha }\end{array}$ & P20100 & Outros produtos químicos industriais \\
\hline 81. & chem & Chemicals & R200 & $\begin{array}{l}\text { Fabricação de produtos quimicos, } \\
\text { plásticos e de borracha }\end{array}$ & P20210 & Adubos e pestecidas \\
\hline 82. & chem & Chemicals & R200 & $\begin{array}{l}\text { Fabricação de produtos quimicos, } \\
\text { plásticos e de borracha }\end{array}$ & P20220 & $\begin{array}{l}\text { Tintas, vernizes, resinas sintéticas e } \\
\text { materiais plásticas }\end{array}$ \\
\hline 83. & chem & Chemicals & R200 & $\begin{array}{l}\text { Fabricação de produtos quimicos, } \\
\text { plásticos e de borracha }\end{array}$ & P20231 & $\begin{array}{l}\text { Sabões e sabonetes, detergentes, } \\
\text { produtos de limpeza }\end{array}$ \\
\hline 84. & chem & Chemicals & R200 & $\begin{array}{l}\text { Fabricação de produtos quimicos, } \\
\text { plásticos e de borracha }\end{array}$ & P20290 & Produtos químicos diversos \\
\hline 85. & chem & Chemicals & $\mathrm{R} 200$ & $\begin{array}{l}\text { Fabricação de produtos quimicos, } \\
\text { plásticos e de borracha }\end{array}$ & P21000 & Produtos farmacêuticos \\
\hline 86. & chem & Chemicals & R200 & $\begin{array}{l}\text { Fabricação de produtos quimicos, } \\
\text { plásticos e de borracha }\end{array}$ & P22110 & Pneus e câmaras de ar \\
\hline 87. & chem & Chemicals & R200 & $\begin{array}{l}\text { Fabricação de produtos quimicos, } \\
\text { plásticos e de borracha }\end{array}$ & P22190 & Outros artigos de borracha \\
\hline 88. & chem & Chemicals & R200 & $\begin{array}{l}\text { Fabricação de produtos quimicos, } \\
\text { plásticos e de borracha }\end{array}$ & P22200 & Artigos de plástico \\
\hline
\end{tabular}




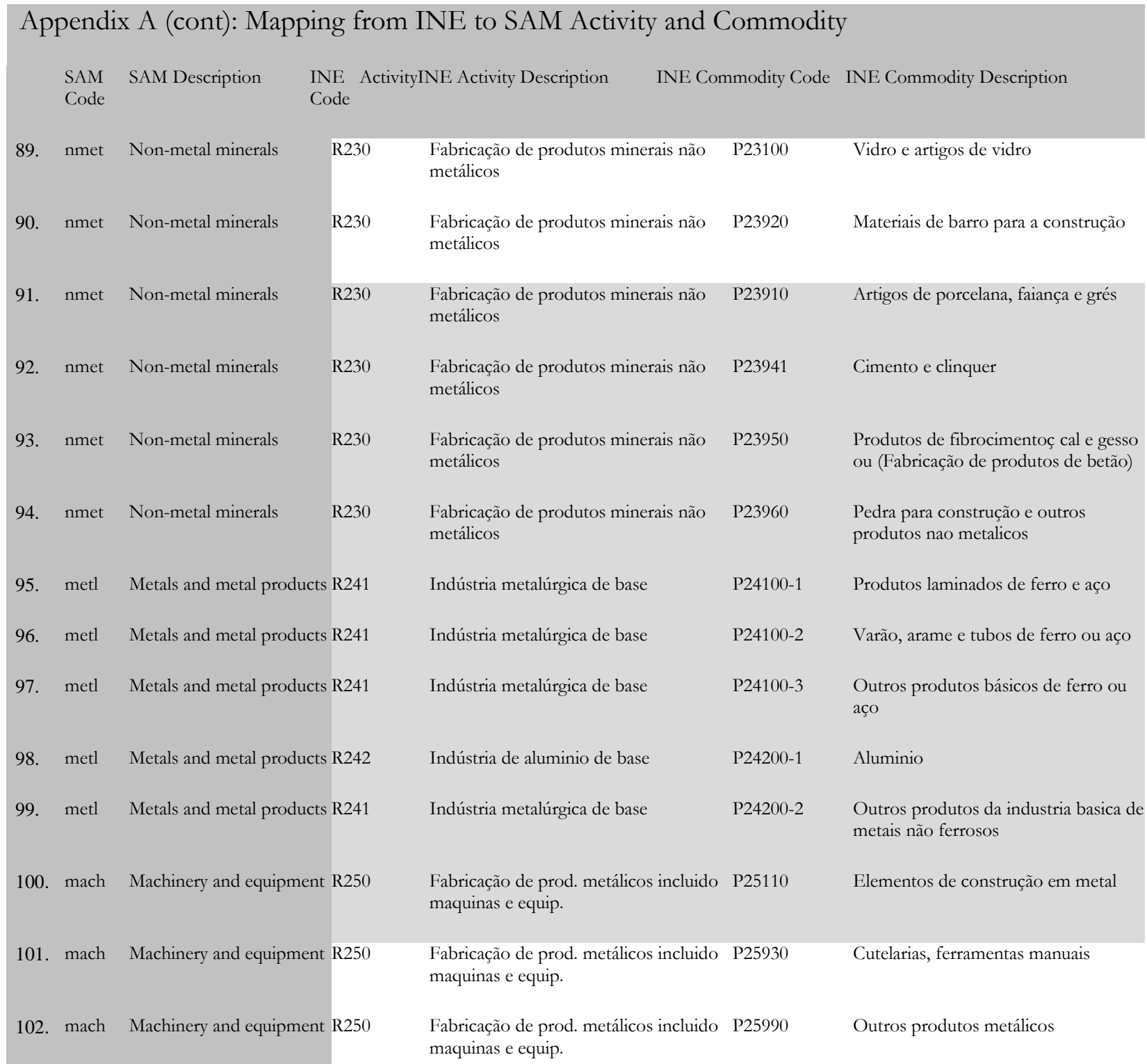

103. mach Machinery and equipment R250

104. mach Machinery and equipment R250

105. mach Machinery and equipment R250

106. mach Machinery and equipment R250

107. mach Machinery and equipment R250

108. mach Machinery and equipment R250

109. mach Machinery and equipment R250

110. mach Machinery and equipment R250
Fabricação de prod. metálicos incluido P26200 maquinas e equip.

Fabricação de prod. metálicos incluido P26400 maquinas e equip.

Fabricação de prod. metálicos incluido P26999 maquinas e equip.

Fabricação de prod. metálicos incluido P27500 maquinas e equip.

Fabricação de prod. metálicos incluido P27900 maquinas e equip.

Fabricação de prod. metálicos incluido P28210 maquinas e equip.

Fabricação de prod. metálicos incluido P28240 maquinas e equip.
Maquinas de escritorio e equipamento

Equipamento e aparelhos de radio, TV e comunicacoes

Outros produtos electrónicos e ópticos

Aparelhos para uso doméstico, electrico e não electrico

Maquinas e aparelhos electricas exc. para uso doméstico

Tractores e seus acessórios, maquinas e equipamentos agricolas

Máquinas para as indústrias extractivas e para construção

Outras maquinarias e equipamento 


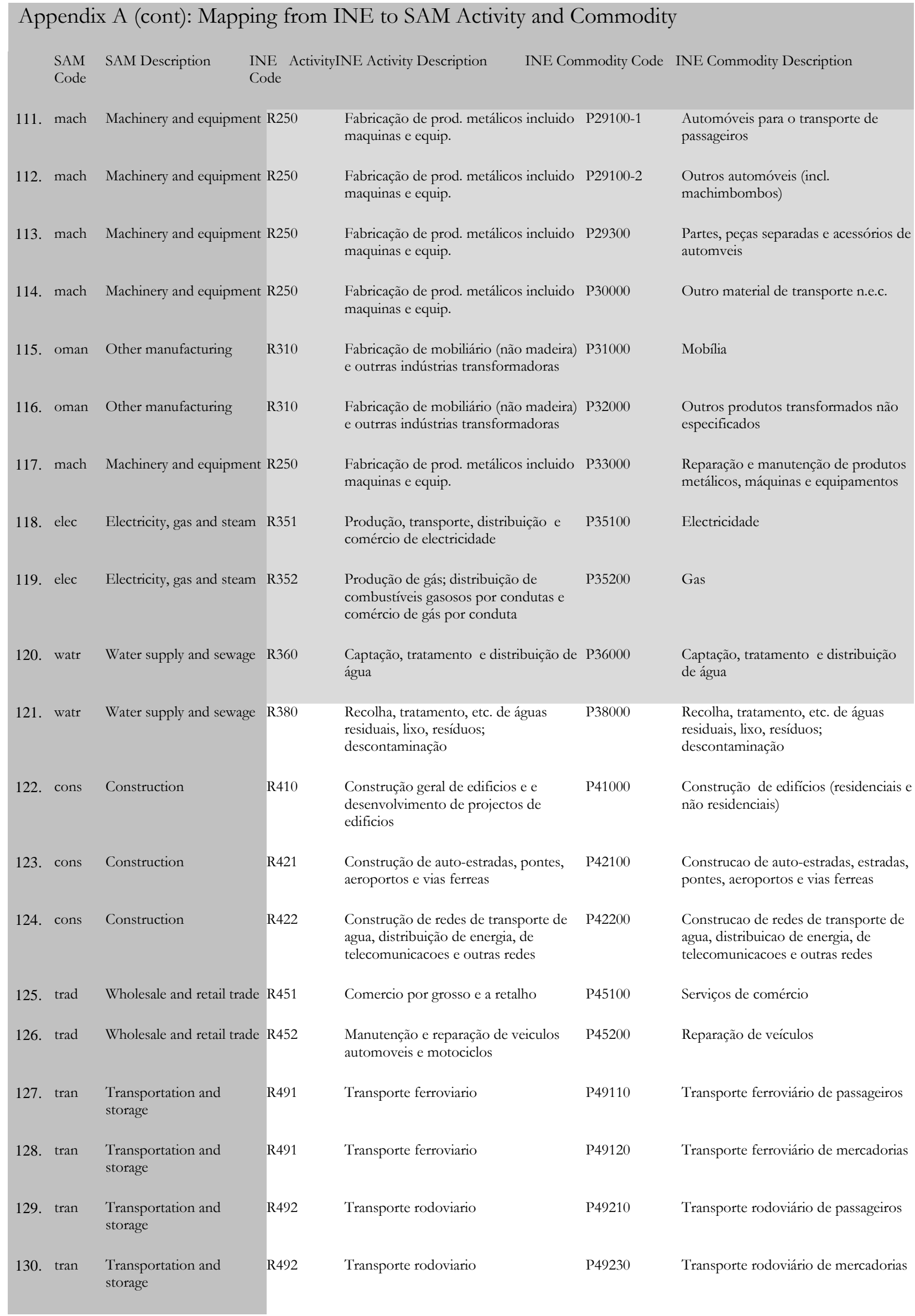




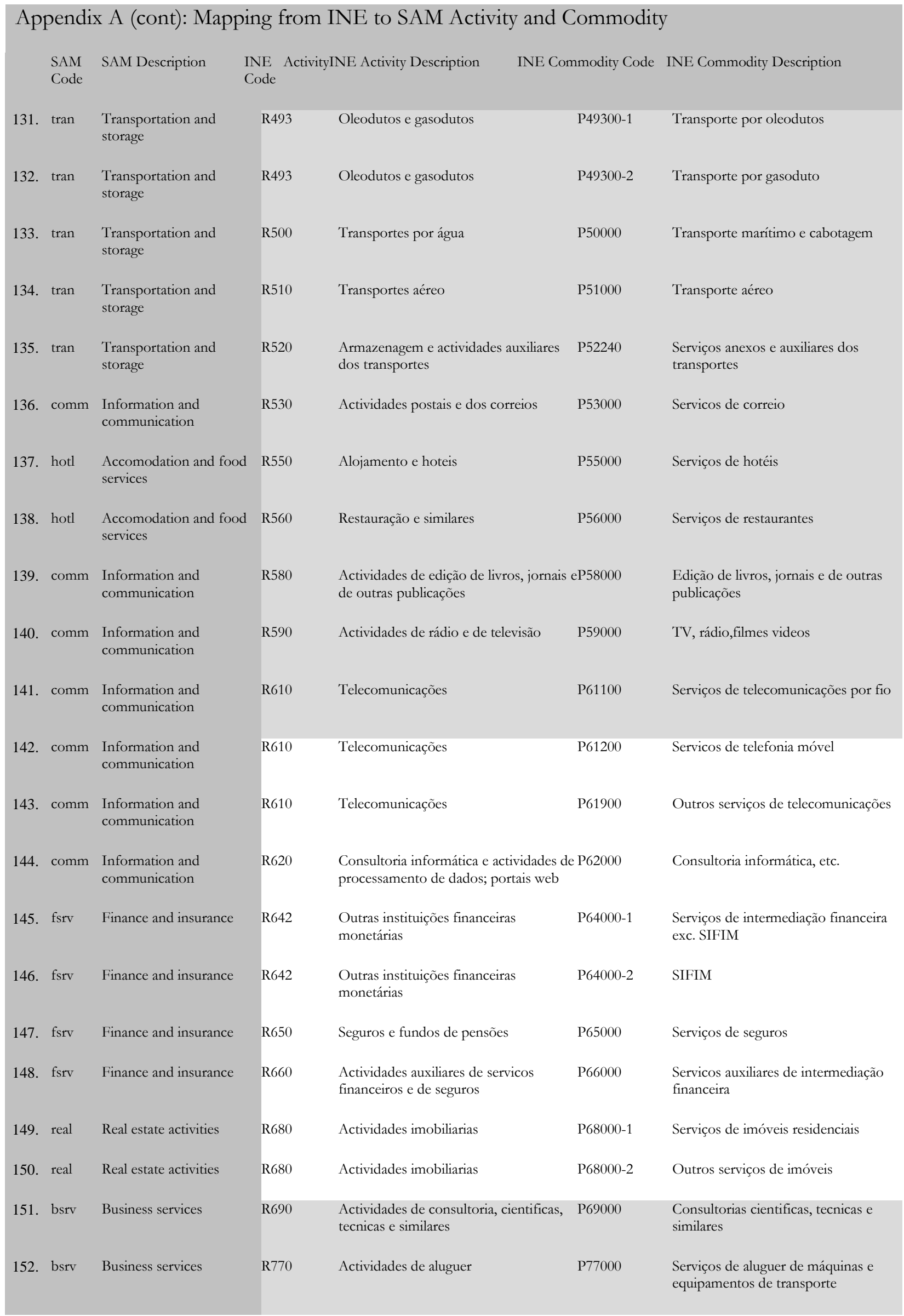




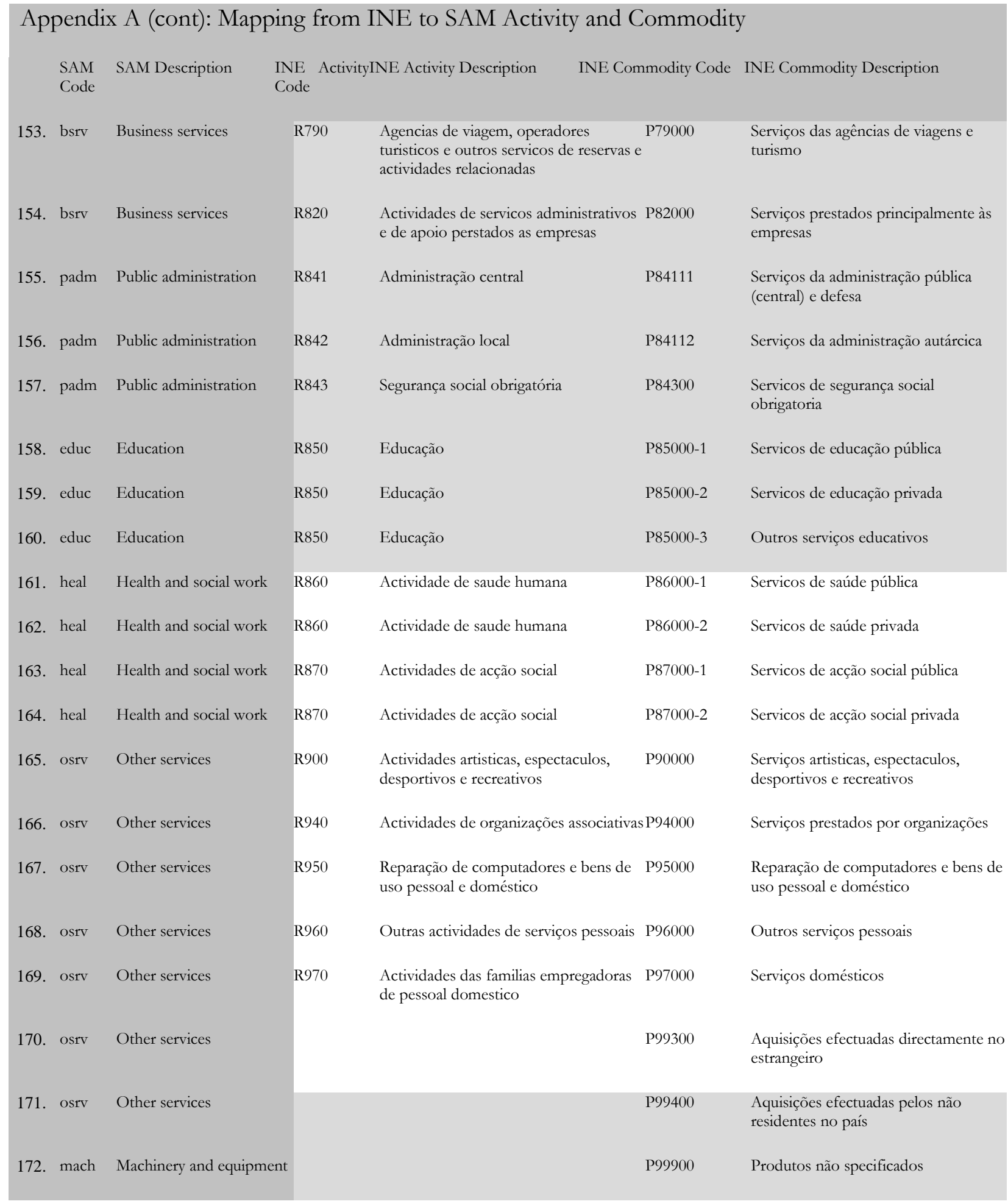

Source: Authors' own compilation. 


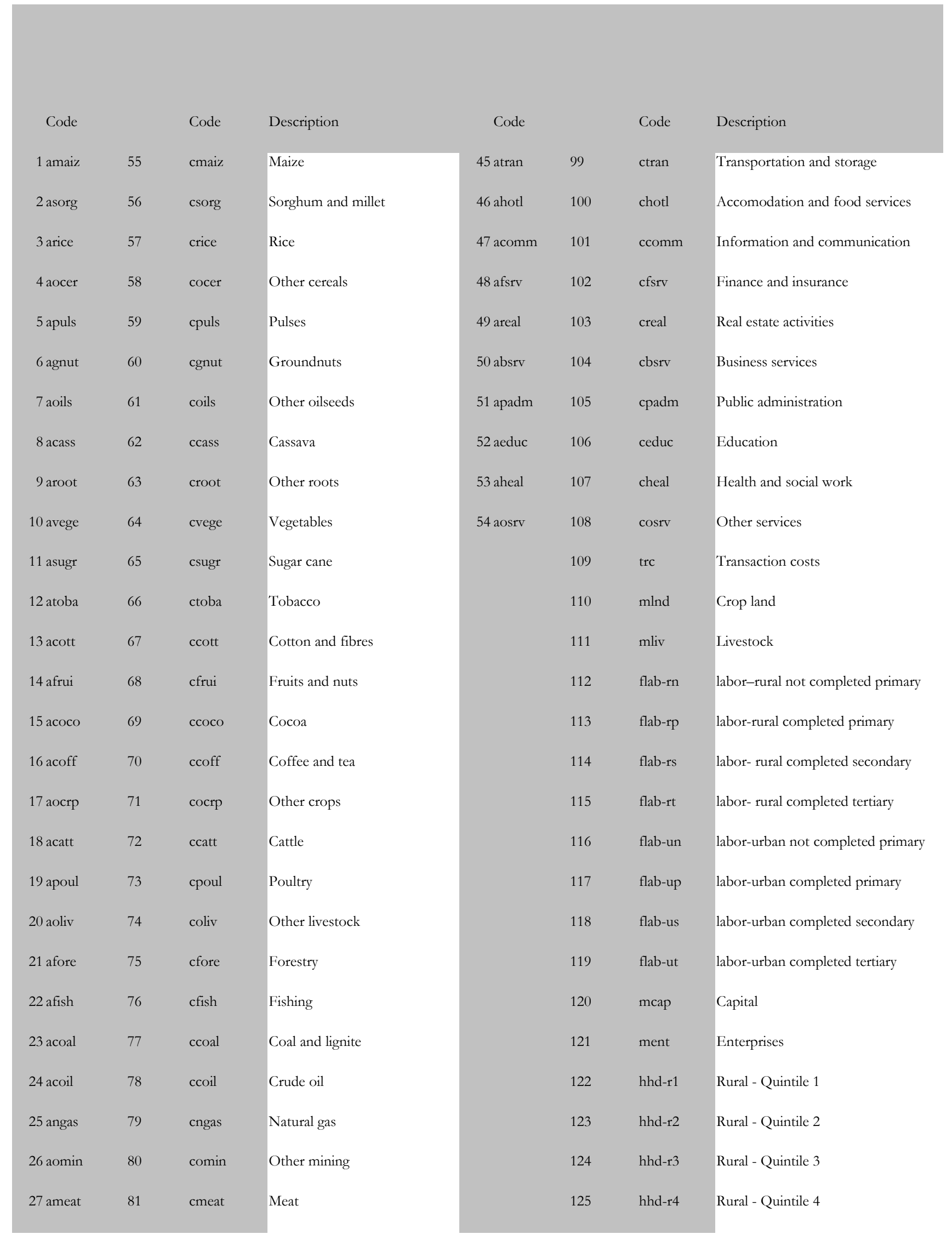




\begin{tabular}{|c|c|c|c|}
\hline 28 acvgp & 82 & ccvgp & Cereal and veg processing \\
\hline 29 afood & 83 & cfood & Other foods \\
\hline 30 aptob & 84 & cptob & Tobacco processing \\
\hline 31 atext & 85 & ctext & Textiles \\
\hline 32 aclth & 86 & cclth & Clothing \\
\hline 33 aleat & 87 & cleat & Leather and footwear \\
\hline 34 awood & 88 & cwood & Wood and paper \\
\hline 35 apetr & 89 & cpetr & Petroleum \\
\hline 36 achem & 90 & cchem & Chemicals \\
\hline 37 anmet & 91 & cnmet & Non-metal minerals \\
\hline 38 ametl & 92 & cmetl & Metals and metal products \\
\hline 39 amach & 93 & $\mathrm{cmach}$ & Machinery and equipment \\
\hline 40 aoman & 94 & coman & Other manufacturing \\
\hline 41 aelec & 95 & celec & Electricity, gas and steam \\
\hline 42 awatr & 96 & cwatr & Water supply and sewage \\
\hline 43 acons & 97 & ccons & Construction \\
\hline 44 atrad & 98 & ctrad & Wholesale and retail trade \\
\hline
\end{tabular}

\begin{tabular}{|c|c|c|}
\hline 126 & hhd-r5 & Rural - Quintile 5 \\
\hline 127 & hhd-u1 & Urban - Quintile 1 \\
\hline 128 & hhd-u2 & Urban - Quintile 2 \\
\hline 129 & hhd-u3 & Urban - Quintile 3 \\
\hline 130 & hhd-u4 & Urban - Quintile 4 \\
\hline 131 & hhd-u5 & Urban - Quintile 5 \\
\hline 132 & mgov & Government \\
\hline 133 & matx & Taxes - Activity \\
\hline 134 & $\mathrm{mftx}$ & Taxes - Factors \\
\hline 135 & mstx & Taxes - Sales \\
\hline 136 & mmtx & Taxes - Import \\
\hline 137 & metx & Taxes - Export \\
\hline 138 & mdtx & Taxes - Direct \\
\hline 139 & mstk & Change in stocks \\
\hline 140 & $\mathrm{~ms}-\mathrm{i}$ & Savings-Investment \\
\hline 141 & mrow & Rest of world \\
\hline
\end{tabular}

Note: not all accounts contain data

Source: Authors' own compilation. 